\title{
PERBANDINGAN KADAR FENOLIK DAN AKTIVITAS ANTIMIKROBA RIMPANG JERINGAU (Acorus calamus) SEGAR DAN TERFERMENTASI
}

\author{
Fitri Hardiansi' ${ }^{1}$, Dwi Afriliana ${ }^{1)}$, Anita Munteira' ${ }^{1)}$, Ernanin Dyah Wijayanti ${ }^{*}$ )
}

${ }^{1)}$ Akademi Farmasi Putra Indonesia Malang J1. Barito No. 5 Malang, (0341) 491132

Korespondensi: nanin.wijayanti@gmail.com

\begin{abstract}
Calamus rhizome contain phenolic as antimicrobial agent. Fermentation can increase the releasing of phenolic content from plant cells. The aim of this research was to observe the comparison of phenolic content and antimicrobial activity between fresh and fermented calamus rhizome extract. Phenolic content was determined by using Folin-Ciocalteu method, and antimicrobial test by agar well diffusion. Phenolic content of fresh and fermented calamus rhizome extract respectively are $97,272 \pm 0,525$ and $223,553 \pm 3,542 \mathrm{mgGAE} / \mathrm{gram}$. Inhibiton zone against Staphylococcus aureus are 4,04 $\pm 0,05$ and $8,24 \pm 0,58 \mathrm{~mm}$, while against Candida albicans are 14,90 $\pm 0,57$ and 18,16 $\pm 1,47 \mathrm{~mm}$. Fermentation increase phenolic content and antimicrobial activity of calamus rhizome.
\end{abstract}

Key words: antimicrobial, calamus rhozome, fermentation, phenolic

\begin{abstract}
ABSTRAK
Rimpang jeringau memiliki kandungan senyawa fenolik sebagai antimikroba. Fermentasi dapat meningkatkan pelepasan senyawa fenolik pada sel tanaman. Penelitian ini bertujuan untuk mengetahui perbandingan kadar fenolik dan aktivitas antimikoba ekstrak rimpang jeringau segar dan terfermentasi. Penetapan kadar fenolik dilakukan dengan metode FolinCiocalteu dan uji antimikroba dengan metode difusi sumuran. Kadar fenolik ekstrak jeringau segar dan fermentasi secara berurutan sebesar 97,272 $\pm 0,525$ dan 223,553 $\pm 3,542$ mgGAE/gram. Daya hambat rimpang jeringau segar dan terfermentasi terhadap Staphylococcus aureus sebesar 4,04 $\pm 0,05$ dan 8,24 $\pm 0,58 \mathrm{~mm}$, sedangkan terhadap Candida albicans sebesar $14,90 \pm 0,57$ dan $18,16 \pm 1,47 \mathrm{~mm}$. Fermentasi dapat meningkatkan kadar fenolik dan aktivitas antimikroba rimpang jeringau.
\end{abstract}

Kata kunci: antimikroba, fenolik, fermentasi, rimpang jeringau 


\section{PENDAHULUAN}

Jeringau (Acorus calamus) merupakan salah satu tanaman rimpangrimpangan yang telah banyak digunakan oleh masyarakat sebagai tanaman obat. Rimpang jeringau diketahui dapat digunakan sebagai obat tradisional untuk penyakit infeksi, baik yang disebabkan oleh bakteri maupun fungi. Rita et al. (2018) menyatakan bahwa ekstrak etanol rimpang jeringau memiliki aktivitas antibakteri terhadap Escherichia coli dan Staphylococcus aureus serta memiliki aktivitas antifungi terhadap Candida albicans.

Kemampuan rimpang jeringau sebagai antimikroba disebabkan karena adanya adanya kandungan fitokimia. Menurut Barua et al (2014), ekstrak etanol rimpang jeringau mengandung senyawa fenolik dan flavonoid dengan kadar tertinggi, selanjutnya yaitu senyawa alkaloid, terpen dan tannin. Dhaniaputri (2015) menyatakan bahwa kandungan senyawa metabolit sekunder pada tumbuhan tersimpan pada bagian vakuola. Berdasarkan struktur sel tumbuhan, letak vakuola yaitu pada bagian dalam sel tumbuhan dan dilindungi oleh dinding sel, dimana dinding sel pada tumbuhan inilah yang menyebabkan sel tumbuhan lebih keras dibanding sel hewan yang tidak memiliki dinding sel. Menurut Srivastava et al (2017), dinding sel adalah lapisan luar yang kuat pada sel tanaman dengan komponen selulosa dan lignin yang keras.

Untuk mendapatkan senyawa metabolit sekunder seperti flavonoid dan tanin yang terdapat pada rimpang jeringau, maka perlu dilakukan ekstraksi sehingga senyawa tersebut dapat keluar dari dalam sel. Namun karena kuatnya dinding sel tumbuhan, diperlukan upaya lain untuk membantu meningkatkan pelepasan senyawa metabolit sekunder dari dalam sel tumbuhan dengan cara melunakkan atau merusak dinding sel. Salah satu metode yang dapat dilakukan adalah dengan fermentasi. Melalui pro-ses fermentasi, terjadi perombakan senyawa organik kompleks menjadi lebih sederhana, sehingga diharapkan dinding sel akan lebih mudah ditembus oleh pelarut. Salah satu jenis fermentasi yang dapat digunakan dan mudah dalam penerapannya adalah fermentasi alami.

Djonny (2018) menyatakan bahwa fermentasi merupakan salah satu metode rekayasa proses, prinsip dari rekayasa fermentasi ini ditujukan untuk menghancurkan jaringan rimpang jeringau dengan cara memecahkan dinding sel rambut kelenjar dari rimpang jeringau dengan menggunakan enzim yang terdapat dalam mikroorganisme. Me-nurut Sulasiyah dkk (2018), proses fermentasi menyebabkan kadar fenol me-ningkat.

Peningkatan kadar fenolik diharapkan berpengaruh terhadap aktivitas antimikroba yang dimiliki rimpang jeringau, dimana sebelumnya diketahui rimpang jeringau segar memiliki aktivitas antibakteri terhadap Staphylococcus aureus dan aktivitas antifungi terhadap Candida albicans. Tujuan dari pene-litian ini yaitu untuk mengetahui perbandingan kadar fenolik, serta aktivitas antimikroba ekstrak jeringau segar dan terfermentasi.

\section{METODE PENELITIAN Bahan}

Bahan yang digunakan adalah rimpang jeringau segar, kultur Staphylococcus aureus, kultur Candida albicans, asam galat (Sigma Aldrich), reagen Folin-Ciocalteau (Merck $\mathrm{KGaA}$, Na2 CO3, etanol 70\%, $\mathrm{HCl}$, serbuk $\mathrm{Mg}, \mathrm{Fe} \mathrm{Cl} 3 \mathrm{10} \%, \mathrm{NaCl} 0,9 \%$, aquades, media MSA (Merck), media SDA (Oxoid) dan media MHA (Oxoid) yang diperkaya dengan glukosa $2 \%$, 
Fermentasi berdasarkan Widyasaputra dan Yuwono (2013) yang dimodifikasi. Rimpang jeringau dipotong-potong, ditimbang sebanyak 320 gram, kemudian dibiarkan dalam wadah tertutup selama 8 hari.

\section{Ekstraksi}

Menggunakan metode ekstraksi cara basah (Rifkowaty dan Wardanu, 2016). Hasil dari fermentasi rimpang jeringau dihaluskan, ditimbang 60 gram, dimaserasi dalam pelarut etanol $70 \%$ dengan perbandingan bahan dan pelarut 1:8. pPengadukan secara kontinyu dilakukan selama 24 jam pada suhu ruang. Hasil ekstraksi kemudian disaring menggunakan pompa vakum, setelah itu dipekatkan menggunakan rotary evaporator.

\section{Identifikasi Fitokimia}

Dilakukan terhadap senyawa flavonoid dan tanin. Identifikasi flavonoid, sampel sebanyak $2 \mathrm{~mL}$ dimasukkan ke dalam tabung reaksi, kemudian ditambahkan $0,5 \mathrm{~mL} \mathrm{HCl}$ pekat dan serbuk $\mathrm{Mg}$. Positif mengandung flavonoid jika menghasilkan warna kuning, orange dan merah (dimofikasi dari Wijayanti and Setiawan, 2017). Identifikasi tanin, sampel ditambahkan dengan $1 \mathrm{~mL}$ larutan $\mathrm{FeCl} 3 \quad 10 \%$. Jika terbentuk warna biru tua, biru kehitaman atau hitam kehijauan menunjukkan adanya tanin (dimodifikasi dari Wijayanti dan Susilowati, 2017).

\section{Penetapan Kadar Fenolik}

1. Penentuan Panjang Gelombang Maksimum dan Operating Time

Asam galat sebanyak $50 \mathrm{mg}$ ditambahkan aquades hingga $100 \mathrm{~mL}$ sehingga didapatkan larutan baku induk 500 ppm. Larutan baku induk diambil 0,5 $\mathrm{mL}$ dan dimasukkan ke dalam labu ukur $10 \mathrm{~mL}$, ditambahkan reagen Folin Ciocalteu, kemudian dikocok dan didiamkan selama 5 menit. Ke dalam larutan tersebut ditambahkan $2 \mathrm{~mL}$ larutan $\mathrm{Na} 2 \mathrm{CO} 3 \quad 20 \%$, dikocok homogen dan didiamkan selama 5 menit. Selanjutnya ditambahkan aquades hingga $10 \mathrm{~mL}$ dan dibaca panjang gelombang pada rentang $\square$ 600-800 nm (modifikasi dari Sari dan Ayuchecaria, 2017). Larutan asam galat diamati absorbansi pada panjang gelombang maksimal yang didapatkan tiap 5 menit selama 110 menit.

2. Penentuan Kurva Baku Asam Galat Larutan asam galat dibuat dalam konsentrasi 100, $200,250,300,400$ ppm. Sebanyak $0,2 \mathrm{~mL}$ larutan asam galat berbagai konsentrasi ditambahkan $2,3 \mathrm{~mL}$ aquades dan $0,5 \mathrm{~mL}$ reagen Folin Ciocalteu, dikocok dan didiamkan 5 menit pada suhu $25^{\circ} \mathrm{C}$. Selanjutnya ditambahkan $3 \mathrm{~mL}$ larutan $\mathrm{Na} 2 \mathrm{CO} 3$ $20 \%$ kemudian dikocok kembali hingga homogen dan didiamkan selama 90 menit pada suhu ruang. Larutan berwarna biru kemudian dianalisis dengan spektrofotometer UV-VIS (Genesys 10S UV-Vis) pada panjang gelombang $710 \mathrm{~nm}$. Kurva standar dibuat dengan memasukkan konsentrasi asam galat (ppm) terhadap absorbansi.

3. Penetapan Kadar Fenolik Total

Sampel ditimbang sebanyak $10 \mathrm{mg}$ dan dilarutkan dengan etanol $70 \%$ hingga 10 $\mathrm{mL}$. Kemudian diambil sebanyak 0,2 $\mathrm{ml}$, ditambahkan 2,3 $\mathrm{mL}$ aquades dan 0,5 mL reagen Folin Ciocalteu, dikocok dan didiamkan selama 5 menit pada suhu $25^{\circ} \mathrm{C}$. Selanjutnya ditambahkan 3 $\mathrm{mL}$ larutan $\mathrm{Na} 2 \mathrm{CO} 3$ 20\% kemudian dikocok kembali hingga homogen dan didiamkan selama 90 menit pada suhu ruang. Larutan berwarna biru kemudian dianalisis dengan spektrofotometer UVVIS pada panjang gelombang $710 \mathrm{~nm}$.

\section{Pengujian Aktivitas Antimikroba}

Masing-maing kultur mikroba uji dibuat suspensi menggunakan standar Mc Farland 0,5. Uji aktivitas antimikroba dilakukan menggunakan metode difusi sumuran (modifikasi Candrasari dkk, 2012). Masing-masing suspensi mikroba uji dimasukkan ke dalam cawan petri sebanyak $1 \mathrm{~mL}$, kemudian 
dituang media MHA (C. albicans) dan dibiarkan memadat. Selanjutnya dibuat sumuran dengan diameter $10 \mathrm{~mm}$ menggunakan cork borer dan diisi dengan 0,5 gram ekstrak etanol rimpang jeringau segar dan terfermentasi. Inkubasi dilakukan selama 24 jam pada suhu 36-370C. Pengamatan dilakukan dengan melihat ada tidaknya zona hambat di sekitar sumuran. Diameter zona hambat diukur menggunakan jangka sorong.

\section{HASIL DAN PEMBAHASAN}

Fermentasi rimpang jeringau dilakukan secara alami tanpa penambahan starter. Menurut Widyasaputra dan Yuwono (2013), fermentasi alami melibatkan berbagai macam mikroorganisme yang tumbuh secara alami pada bahan yang akan difermentasi dan berpengaruh terhadap sifat fisika dan kimia dari bahan tersebut. Fermentasi dilakukan dalam wadah tertutup selama 8 hari dengan indikator tekstur dan aroma jeringau. Perubahan yang terjadi pada saat proses fermentasi menunjukkan adanya aktivitas mikroba yang berpengaruh terhadap perubahan struktur rimpang. Rimpang jeringau menjadi semakin lembek dan mengeluarkan bau khas jeringau yang lebih menyengat. Hal ini menunjukkan bahwa dinding sel rimpang jeringau telah rusak sehingga dapat mempermudah proses ekstraksi senyawa metabolit.

Adanya proses fermentasi pada rimpang jeringau juga berpengaruh terhadap rendemen ekstrak yang dihasilkan. Ekstrak rimpang jeringau segar memiliki rendemen sebesar $14,50 \%$, sedangkan ekstrak rimpang jeringau terfermentasi memiliki rendemen yang lebih tinggi yaitu sebesar 18,67\%. Hal ini menunjukkan bahwa proses fermentasi dapat membantu pelepasan senyawa fitokimia pada sel tumbuhan sehingga lebih banyak yang terekstraksi.
Identifikasi fitokimia dilakukan untuk mengonfirmasi adanya kandungan senyawa fenolik pada ekstrak rimpang jeringau sebelum dilakukan penetapan kadar senyawa fenolik. Berdasarkan hasil pengujian identifikasi fitokimia yang telah dilakukan, diketahui bahwa baik pada ekstrak rimpang jeringau segar maupun terfermentasi positif mengandung flavonoid dan tanin, dimana kedua senyawa tersebut termasuk dalam senyawa fenolik. Hal ini sesuai dengan hasil beberapa penelitian sebelumnya yang menyatakan rimpang jeringau mengandung senyawa flavonoid dan tanin (Barua et al., 2014; Anisah dkk., 2014; Muthulakshmi et al., 2015).

Berdasarkan hasil pengukuran absorbansi larutan asam galat pada konsentrasi 100-400 ppm diperoleh kurva standar asam galat dengan persamaan regresi linier $y=0,0033 x+$ 0,05 dengan koefisien korelasi (R2) 0,9783. Maka diperoleh hasil perhitungan kadar fenolik yang dapat dilihat pada tabel 1.

Tabel 1. Kadar Fenolik Ekstrak Rimpang Jeringau

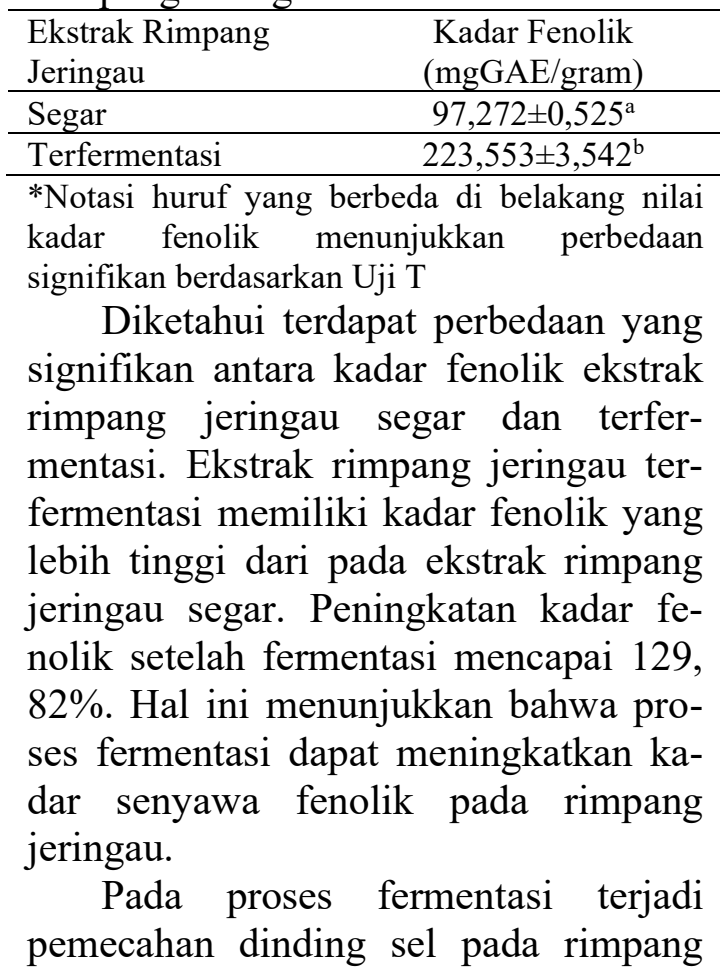


sehingga senyawa yang terdapat pada vakuola keluar lebih optimal. Selain itu, pada proses fermentasi juga terdapat bakteri alami yang terdapat pada rimpang jeringau yang ikut berperan di dalamnya. Menurut Ayuratri dan Kusnadi (2017), adanya mikroorganisme yang bermetabolisme dapat meningkatkan senyawa fenol melalui reaksi enzimatis sehingga dapat mempengaruhi total fenol. Menurut Sulasiyah dkk (2018) fermentasi dapat meningkatkan kadar fenolik karena kandungan senyawa fenolik pada rimpang yang difermentasi mengalami transformasi ke bentuk bebasnya yaitu aglikon, selain itu proses fermentasi adalah proses yang cukup efektif dalam meningkatkan komponen fenolik.

Hasil penelitian ini sejalan dengan hasil penelitian lain dimana terjadi peningkatan kadar fenolik setelah difermentasi, yaitu pada sari temu giring segar dan terfermentasi mengalami peningkatan sebesar 547\% (Murelina dan Wijayanti, 2018), pada seduhan daun gaharu dan kombuca daun gaharu mengalami peningkatan sebesar 220\% (Nurmiati dan Wijayanti, 2018), pada fermentasi asam laktat jus buah tin kandungan fenolik meningkat antara $100 \%$ hingga $400 \%$ (Wijayanti et al, 2017) dan pada fermentasi ekstrak kunyit kandungan fenolik meningkat sebesar 43,4\% (Sulasiyah dkk., 2018)

Rimpang jeringau diketahui memiliki aktivitas antimikroba karena adanya senyawa fenolik. Menurut Rita et al. (2019), aktivitas antimikroba rimpang jeringau berkorelasi positif dengan kadar senyawa fenol dan flavonoid. Oleh karena itu, adanya peningkatan kadar senyawa fenolik pada penelitian ini diharapkan juga berkorelasi dengan peningkatan aktivitas antimikroba rimpang jeringau. Hasil pengujian aktivitas antimikroba ekstrak rimpang jeringau segar dan terfermentasi terhadap mikroba indikator yaitu $S$. aureus dan C. albicans dapat dilihat pada tabel 2 .

Tabel 2. Hasil Uji Aktivitas Antimikroba Ekstrak Rimpang Jeringau

\begin{tabular}{lcc}
\hline $\begin{array}{c}\text { Ekstrak Rimpang } \\
\text { Jeringau }\end{array}$ & \multicolumn{2}{c}{$\begin{array}{c}\text { Diameter Zona Hambat (mm) } \\
\text { terhadap: }\end{array}$} \\
\cline { 2 - 3 } & $\begin{array}{c}\text { Staphylococcus } \\
\text { aureus }\end{array}$ & $\begin{array}{c}\text { Candida albi- } \\
\text { cans }\end{array}$ \\
\hline Segar & $4,04 \pm 0,16^{\mathrm{a}}$ & $14,90 \pm 0,57^{\mathrm{a}}$ \\
\hline Terfermentasi & $8,24 \pm 0,58^{\mathrm{b}}$ & $18,16 \pm 1,47^{\mathrm{a}}$ \\
\hline *Notasi huruf yang berbeda di belakang nilai & bang & bolom yang sama \\
diameter zona hambat pada kom & \\
menunjukkan perbedaan signifikan berdasarkan \\
Uji T
\end{tabular}

Berdasarkan tabel 2 dapat diketahui bahwa ekstrak rimpang jeringau terfermentasi memiliki aktivitas antimikroba yang lebih besar dari pada ekstrak rimpang jeringau segar. Aktivitas antimikroba pada ekstrak rimpang jeringau disebabkan karena adanya kadungan senyawa fenolik, antara lain flavonoid dan tanin. Senyawa flavonoid memiliki mekanisme kerja sebagai antibakteri dengan cara menggangu dinding sel (Savoia, 2012 dalam Novitasari dan Wijayanti, 2018) sedangkan sebagai antifungi dengan mengganggu membran sel, disfungsi mitokondria, menghambat pembentukan dinding sel dan pembelahan sel (Freiesleben and Jager, 2014). Tanin merupakan senyawa metabolit sekunder pada tumbuhan yang bersifat sebagai agen antimikroba dengan cara membentuk ikatan yang stabil dengan protein sehingga terjadi koagulasi protoplasma mikroba (Susanti, 2016).

Berdasarkan data pada tabel 2 juga dapat diketahui bahwa terdapat perbedaan yang signifikan pada aktivitas antibakteri antara ekstrak jeringau segar dan terfermentasi, namun aktivitas antifunginya tidak berbeda secara signifikan meskipun terjadi peningkatan diameter zona hambat pada ekstrak jeringau terfermentasi. Apabila dikaitkan dengan hasil penentuan kadar fenolik, maka hal ini menunjukkan adanya korelasi positif antara 
peningkatan kadar senyawa fenolik ekstrak rimpang jeringau dengan aktivitasnya sebagai antimikroba, terutama antibakteri.

\section{KESIMPULAN}

Ekstrak rimpang jeringau segar memiliki perbedaan kadar senyawa fenolik dan aktivitas antibakteri dengan ekstrak rimpang jeringau terfermentasi, sedangkan aktivitas antifungi tidak berbeda secara signifikan. Baik kadar fenolik maupun aktivitas antimikroba ekstrak rimpang jeringau mengalami peningkatan setelah proses fermentasi. Perlu diakukan penentuan waktu optimal fermentasi yang menghasilkan kadar fenolik tertinggi.

\section{DAFTAR PUSTAKA}

Anisah, Khotimah, S., \& Yanti, H.A., 2014, 'Aktivitas Antibakteri Ekstrak Rimpang Jeringau (Acorus calamus L.) terhadap Pertumbuhan Staphylococcus aureus dan Escherichia coli', Jurnal Protobiont 3 (3), 1-5.

Ayuratri, M.K., \& Kusnadi, J., 2017, 'Aktivitas Antibakteri Kombucha Jahe (Zingiber officinale) (Kajian Varietas Jahe dan Konsentrasi Madu)', Jurnal Pangan dan Agroindustri 5 (3), 95-107.

Barua, C.C., Sen, S., Sundar, D.A., Talukdar, A., Hazarika, N.J., Barua, A.G., 2014, 'A Compartive Study of The In Vitro Antioxidant Property of Different Extracts of Acorus calamus Linn.', Journal of Natural Product and Plant Resource 4 (1), 8-18.

Candrasari, A., Romas, M.A., Hasbi, M., \& Astuti, O.R., 2012, 'Uji Daya Antimikroba Ekstrak Etanol Daun Sirih Merah (Piper crocatum Ruiz \& Pav.) Terhadap Pertumbuhan Staphylococcus aureus ATCC 6538, Eschericia coli ATCC 11229 dan Candida albicans ATCC 10231 secara in vitro', Jurnal Biomedika 4 (1), 916.

Dhaniaputri, R., 2015, 'Mata Kuliah Struktur dan Fisiologi Tumbuhan sebagai Pengantar Pemahaman Proses Metabolisme Senyawa Fitokimia', Pendidikan Biologi FKIP Universitas Ahmad Dahlan, Yogyakarta.

Djonny, M., 2018, 'Dampak Rekayasa Proses Bahan Baku pada Penyulingan Minyak Atsiri Jeringau (Acorus calamus)', Sinergitas Multidisiplin Ilmu Pengetahuan dan Teknologi 1.

Freiesleben, S.H and Jager, A.K., 2014, 'Correlation between Plant Secondary Metabolites and Their Antifungal Mechanisms-A Review', Medicinal and Aromatic Plants 3 (2).

Murelina, E.M. \& Wijayanti, E.D., 2018, 'Perbandingan Kadar Fenolik Total Sari Rimpang Temu Giring (Curcuma heyneana) Segar dan Terfermentasi', Journal CisTrans (JC-T) 2 (2), 20-24.

Muthulakshmi, T., Saleh, A.M., Kumari, N.V., Mohana, P.K., Palanichamy, V., 2015, 'Screening of Phytochemicals and in Vitro Antioxidant activity of Acorus calamus', Int. J. Drug Dev. \& Res. 7 (1), 44-51.

Novitasari, E.D. \& Wijayanti, E.D., 2018, 'Aktivitas Antimikroba Teh Asam Daun Tin (Ficus carica) Secara In Vitro', Journal CisTrans (JC-T) 2 (2), 25-29.

Nurmiati \& Wijayanti, E.D., 2018, 'Perbandingan Kadar Fenolik Total Antara Seduhan Daun Gaharu Dan Kombucha Daun Gaharu (Aquailaria malaccensis)', Journal Cis-Trans (JC-T) 2 (1), 611. 
Rifkowaty, E. E., \& Wardanu, A.P., 2016, 'Pengaruh Ekstraksi Cara Basah dan Cara Kering Terhadap Aktivitas Antioksidan Ekstrak Cengkodok (Melastoma malabathricum L.)', Jurnal Aplikasi Teknologi Pangan, 1015.

Rita, W.S., Retno, K., Dira, S.I.M., 2018, 'Total Phenolic and Flavonoid Contents and Antimicrobial activity of Acorus calamus L. Rhizome Ethanol Extract', Research Journal of Chemistry and Environment 22 (Special Issue II), 65-70.

Rita, W.S., Swantara, I.M.D., Utami, G.A.P., 2019, 'Antimicrobial Activity of Acorus calamus L. Rhizome Extract and Its Total Flavonoid and Phenolic Contents', Proceedings of the 2nd International Conference on Biosciences and Medical Engineering (ICBME2019), AIP Conf. Proc., 2155, 020054-1020054-9; https://doi.org/10.1063/1.5125558

Sari, A.K., \& Ayuchecaria, N., 2017, 'Penetapan Kadar Fenolik Total dan Flavonoid Total Ekstrak Beras Hitam (Oryza Sativa L.) dari Kalimantan Selatan', Jurnal Ilmiah Ibnu Sina, 2 (2), 327-335.

Srivastava, V., Bulone, V., McKee, L.S., 2017, 'Plant Cell Walls', In: eLS. John Wiley \& Sons, Ltd: Chichester. DOI: 10.1002/9780470015902.a000168 2.pub3

Sulasiyah, Sarjono, P.R., \& Aminin, A.L., 2018, 'Antioxidant from
Tumeric Fermentation Product (Curcuma longa) by Aspergillus oryzae', Jurnal of Scientific and Applied Chemistry.

Susanti, N., 2016, 'Aktivitas Antimikroba Ekstrak Rimpang Jeringau (Acorus calamus) terhadap Pertumbuhan Candida albicans', Jurnal Biodjati 1 (1), 55-58.

Widyasaputra, R., \& Yuwono, S.S., 2013, 'Pengaruh Fermentasi Alami Chips Terhadap Sifat Fisik Tepung Ubi Jalar Putih (Ipomoea batatas L.) Fermented Flour', Jurnal Pangan dan Agroindustri 1 (1), 78-89.

Wijayanti, E.D. \& Setiawan, N.C.E., 2017, 'The Effect of Lactic Acid Fermentation on Fig (Ficus carica) Fruit Flavonoid', Journal of Biological Researches 23 (1), 39-44.

Wijayanti, E.D., Setiawan, N.C.E. \& Cristi, J.P., 2017, 'Effect of Lactic Acid Fermentation on Total Phenolic Content and Antioxidant Activity of Fig Fruit Juice (Ficus carica)', Advances in Health Sciences Research (AHSR)2, Atlantis Press, Proceeding of 1st Health Science International Conference, Malang, Indonesia, October 4-5, 2017, pp. 282-289.

Wijayanti, E.D. \& Susilowati, E., 2017, 'Eksplorasi Ekstrak Etanol Beberapa Tumbuhan Berpotensi Sebagai Antiketombe', Jurnal Riset Sains dan Teknologi 1 (2), 75-8. 